\title{
In Vitro Immunoregulatory Effects of Korean Mistletoe Lectin on Functional Activation of Monocytic and Macrophage-Like Cells
}

\author{
Ji Yeon Lee, ${ }^{a}$ Joo Young Kim ${ }^{a}$ Yong Gyu Lee, ${ }^{a}$ Se Eun Byeon, ${ }^{a}$ Byung Hun KIm, ${ }^{a}$ Man Hee Rhee, ${ }^{b}$ \\ Albert LeE, ${ }^{c}$ Moosik Kwon, ${ }^{d}$ Sungyoul Hong, ${ }^{*}, d$ and Jae Youl CHO ${ }^{*, a}$ \\ ${ }^{a}$ School of Bioscience and Biotechnology, and Institute of Bioscience and Biotechnology, Kangwon National University; \\ Chuncheon 200-701, Korea: ${ }^{b}$ Department of Physiology, College of Veterinary Medicine, Kyungpook National University; \\ Daegu 702-701, Korea: ${ }^{c}$ Department of Materials Science and Engineering, Univeristy of Illinois-Urbana-Champaign; \\ Urbana, IL 61801, U.S.A.: and ${ }^{d}$ Department of Genetic Engineering, Sungkyunkwan University; Suwon 440-746, Korea. \\ Received May 10, 2007; accepted August 10, 2007
}

\begin{abstract}
Korean mistletoe lectin (KML) is one of the major active components in Viscum album var. (coloratum), displaying various biological effects such as anti-tumor and anti-metastatic activities. Even though it has been shown to boost host immune defense mechanisms, the immunomodulatory effects of KML on specific immune responses mediated by macrophages have not been fully elucidated. Therefore, in this study, we aimed to demonstrate KML's regulatory roles on macrophage-mediated immune responses. KML clearly blocked lipopolysaccharide (LPS)-induced events [expression of interleukin (IL)-10, nitric oxide (NO) production and phagocytic uptake], and suppressed the normal expression levels of IL-10 (at $2 \mathrm{ng} / \mathrm{ml}$ ) and tumor necrosis factor (TNF)- $\alpha$ (at $10 \mathrm{ng} / \mathrm{ml}$ ). In contrast, (1) the expression of cytokine (TNF- $\alpha$ ) and (2) the generation of reactive oxygen species (ROS) induced by LPS were significantly up-regulated with KML co-treatment. In addition, KML itself increased the mRNA levels of IL-3 and IL-23; phagocytic uptake; the surface levels of co-stimulatory molecules (CD80 and CD86), pattern recognition receptors (PRRs) [such as dectin-1 and toll like receptor (TLR)-2] and adhesion molecules [ $\beta 1$-integrins (CD29) and CD43]; and CD29-mediated cell adhesion events. Finally, according to co-treatment of D-galactose with KML under LPS-induced NO production conditions, KML inhibition seems to be mediated by binding to proteins with D-galactose. Therefore, these data suggest that KML may participate in regulating various macrophage-mediated innate and adaptive responses via binding to surface protein with D-galactose and that some of these may deserve in KML's therapeutic activities such as anti-tumor and antimicrobial effects.
\end{abstract}

Key words Korean mistletoe lectin; Viscum album var. (coloratum); immunomodulation; macrophage function

Macrophage is a type of differentiated tissue cell that originates as a blood monocyte. The cells have several functions including the removal of cell debris, killing pathogenic microorganisms, and the processing and presentation of antigens ingested by lymphocytes. ${ }^{1)}$ Therefore, the activation of macrophages is a key event for effective innate and adaptive immunity. When the body is stimulated by pathologic stimuli or injury, macrophages release 1) numerous pro-inflammatory cytokines $[e . g$. tumor necrosis factor (TNF)- $\alpha$ and interleukin (IL)-1]; 2) chemokines and chemoattractants [e.g. IL8 , macrophage inhibitory protein (MIP-1 $\alpha$ ) and monocyte chemoattractant protein (MCP)-1]; and 3) cytotoxic and inflammatory molecules [e.g. nitric oxide (NO), reactive oxygen species (ROS) and prostaglandin $\left.(\mathrm{PG}) \mathrm{E}_{2}\right]$. In addition, macrophages up-regulate the surface levels of glycoproteins (e.g. co-stimulatory molecules [CD80 and CD86], patternrecognition receptors [PPRs] such as toll-like receptors [TLRs], and adhesion molecules [e.g. selectins and integrins]). ${ }^{2)}$ Although large amounts of macrophage-derived inflammatory mediators can cause severe inflammatory diseases such as septic shock and rheumatoid arthritis, ${ }^{3,4)}$ proper regulation of macrophage function by immunomodulatory molecules could help to protect the host from various pathologic and cancerous attacks. The successful resolution of certain severe conditions, therefore, depends on the effective regulation of macrophage function.

Like European mistletoe (EM, Viscum album agglutinins) clinically used as an anti-cancer agent, ${ }^{5)}$ Korean mistletoe (Viscum album L. var. coloratum) is also a therapeutic herb, traditionally used as a sedative, analgesic, anti-spasmolytic, cardiotonic and anticancer agent, in Korea. ${ }^{6}$ Various chemical components have been identified from Korean mistletoe. These include lectins, steroids, triterpens, sesquiterpene lactones, flavonoids and alkaloids. ${ }^{7-10)}$ Of them, Korean mistletoe lectins (KML: KML-C) have become one of the more notable components in Korean mistletoe, due to its stronger anti-cancer activity than EM lectins (EML-1) against various cancer cell lines. ${ }^{11)}$ These two lectins have different biochemical features in molecular weights (KML: 59.5 and EML: $60 \mathrm{kDa}$ ), PI values (KML: 8.0 to 9.0 and EML: 6.6 to 7.0 ), N-terminal amino acid sequence, and structure. ${ }^{11)}$ Similar to EML, however, KML is known to be D-galactose- and/or $N$ acetyl-D-galactosamine-specific type-2 ribosome-inactivating proteins composed of subunit A (a subunit inactivating the function of the eukaryotic $60 \mathrm{~S}$ ribosomal subunit) and subunit B (a binding subunit to surface glycoproteins or glycoconjugates) linked covalently by a disulfide bond. ${ }^{12,13)}$ It is now assumed that subunit $B$ is able to bind to cell-surface glycoconjugates and consequently permits entry into the cell of the subunit A with a toxic role through inhibiting protein synthesis. ${ }^{14,15)}$ Indeed, several of evidence that KML displays strong apoptosis-inducing activity, and anti-metastatic and anti-angiogenic effects are considered as direct outcomes of the molecular interaction. ${ }^{16-18)}$ In addition, however, KML has also been reported to positively modulate NK cell activity, antigen-specific antibody production, Th1/Th2 responses and induction of cytolytic T lymphocyte activity, ${ }^{19,20)}$ indicating that additional mechanism of KML in addition to simple 
cytotoxic activity could mediate its immunopharmacological actions. Even though the immunomodulatory roles of KML in immune responses are being explored and further elucidated, regulatory activity of KML on specific functions of monocytes/macrophages has not been fully explained so far.

In this study, we therefore aimed to prove the modulatory roles of KML on the functional activation of monocytic and macrophage-like cells. To do this, functional events mediated by activated macrophages such as the expression of cytokines, the release of toxic molecules (NO/ROS), phagocytic uptake, activation of cell adhesion, and the up-regulation of surface PRR levels were evaluated following KML exposure.

\section{MATERIALS AND METHODS}

Materials $\quad N^{\mathrm{G}}$-Monomethyl-L-arginine (N-MMA), Dgalactose, sodium nitroprusside (SNP), genistein, FITC-dextran, peptidoglycan (PGN) and lipopolysaccharide (LPS, E. coli 0111:B4) were purchased from Sigma Chemical Co. (St. Louis, MO, U.S.A.). GF109203X, U0126, SB203580 and SP600125 were obtained from Calbiochem. (La Jolla, CA, U.S.A.). Fibronectin, PE-conjugated antibodies to CD80 and CD86, and FITC conjugated antibodies to TLR-2, TLR-4 and dectin-1 were from PharMingen (San Diego, CA, U.S.A.) and Serotec (Kidlington, Oxford, U.K.), respectively. Dihydrorhodamine 123 (DHR123) and dichlorodihydrofluorescein diacetate $\left(\mathrm{H}_{2} \mathrm{DCFDA}\right)$ were purchased from Molecular Probe (Carlsbad, CA, U.S.A.). Fetal bovine serum and RPMI1640 were obtained from GIBCO (Grand Island, NY, U.S.A.). RAW264.7, Jurkat and U937 cells were purchased from the American Tissue Culture Center (Rockville, MD, U.S.A.). All other chemicals were of Sigma grade. The aggregative antibody to CD29 (MEM101A) and antibodies to CD18, CD62L, CD43, CD98 and CD147 for determining surface levels were used as described previously. ${ }^{21,22)}$ Phospho-antibodies to ERK and p38, and antibodies to ERK and p38 were purchased from Cell Signaling Technologies (Beverly, MA, U.S.A.).

Preparation of KML KML was prepared by a method reported previously. ${ }^{11,23)}$ Briefly, Korean mistletoe (Viscum album L. var. coloratum) growing on oak tree was collected in winter in Kangwon province, Korea. KML was purified from the Korean mistletoe by affinity chromatography on asialofetuin-Sepharose $4 \mathrm{~B}$ as described previously. ${ }^{11,23)}$ The purity determined by SDS-PAGE and densitometric scanning was more than $98 \%$. The purified KML contained a level of endotoxin below the detection limits $(0.0015 \mathrm{EU} / \mathrm{ml})$ as assessed by an Endotoxin assay kit (Sigma, St. Louis, MO, U.S.A.).

Cell Culture RAW264.7, Jurkat and U937 cells were maintained in RPMI1640 supplemented with $100 \mathrm{U} / \mathrm{ml}$ of penicillin, $100 \mu \mathrm{g} / \mathrm{ml}$ of streptomycin, and $10 \%$ fetal bovine serum. Cells were grown at $37^{\circ} \mathrm{C}$ and $5 \% \mathrm{CO}_{2}$ in humidified air.

MTT Assay (Colorimetric Assay) for Measuring Cell Proliferation The cytotoxic effect of KML was evaluated by a conventional MTT assay. At $3 \mathrm{~h}$ prior to culture termination, $10 \mu \mathrm{l}$ of the MTT solution $(10 \mathrm{mg} / \mathrm{ml}$ in a phosphate buffered-saline, $\mathrm{pH}$ 7.4) were added and the cells were continuously cultured until termination. Incubation was stopped by the addition of $15 \%$ sodium dodecyl sulfate in $1.5 \mathrm{~N} \mathrm{HCl}$ to each well for the solubilization of formazan. Optical density (OD) at $570 \mathrm{~nm}\left(\mathrm{OD}_{570-630}\right)$ was measured by a Spectramax 250 microplate reader (Molecular Devices, Sunnyvale, CA, U.S.A.).

RT-PCR For the evaluation of LPS-inducible gene mRNA expression levels, total RNA from LPS treated (or untreated)-RAW264.7 cells was prepared by adding TRIzol Reagent (Gibco BRL), according to the manufacturer's protocol. Total RNA solution was stored at $-70^{\circ} \mathrm{C}$ until used. Semi-quantitative RT reactions were conducted using MuLV reverse transcriptase. Total RNA $(1 \mu \mathrm{g})$ was incubated with oligo-dT ${ }_{15}$ for $5 \mathrm{~min}$ at $70^{\circ} \mathrm{C}$, and was mixed with a $5 \times$ firststrand buffer, $10 \mathrm{~mm}$ of $\mathrm{dNTP}$ and $0.1 \mathrm{~m}$ DTT. The reaction mixture was further incubated for $5 \mathrm{~min}$ at $37^{\circ} \mathrm{C}$, and for $60 \mathrm{~min}$ after the addition of $\mathrm{MuLV}$ reverse transcriptase (2 U). Reactions were terminated for $10 \mathrm{~min}$ at $70^{\circ} \mathrm{C}$ and RNA was depleted by adding RNase $H$. The PCR reaction was conducted with the incubation mixture $(2 \mu \mathrm{l}$ cDNA, $4 \mu \mathrm{M} 5^{\prime}$ and $3^{\prime}$ primers, a $10 \times$ buffer [10 mM Tris- $\mathrm{HCl}, \mathrm{pH}$ 8.3, $50 \mathrm{~mm} \mathrm{KCl}, 0.1 \%$ Triton X-100], $250 \mu \mathrm{M}$ of dNTP, $25 \mathrm{~mm}$ of $\mathrm{MgCl}_{2}$, and 1 unit of Taq polymerase [Promega, U.S.A.]) under the following incubation conditions: $45 \mathrm{~s}$ denaturation at $94^{\circ} \mathrm{C}$, annealing for $45 \mathrm{~s}$ between 55 and $60^{\circ} \mathrm{C}$, extension for $60 \mathrm{~s}$ at $72^{\circ} \mathrm{C}$, and a final extension of $7 \mathrm{~min}$ at $72^{\circ} \mathrm{C}$ at the end of 30 cycles. The primers (Bioneer, Seoul, Korea) used in this experiment are indicated in Table 1 (F: forward, R: reverse).

Immunoblotting Cells $\left(5 \times 10^{6}\right.$ cells $\left./ \mathrm{ml}\right)$ were lysed in lysis buffer (in mM: 20 Tris-HCl, pH 7.4, 2 EDTA, 2 EGTA, $50 \beta$-glycerophosphate, 1 sodium orthovanadate, 1 dithiothreitol, $1 \%$ Triton X-100, $10 \%$ glycerol, $10 \mu \mathrm{g} / \mathrm{ml}$ leupeptin, $10 \mu \mathrm{g} / \mathrm{ml}$ aprotinin and $10 \mu \mathrm{g} / \mathrm{ml}$ pepstatin, 1 benzimide and 2 hydrogen peroxide) for $30 \mathrm{~min}$ under rotation in a coldroom. The lysates were clarified by centrifugation at $16000 \times \boldsymbol{g}$ for $10 \mathrm{~min}$ at $4{ }^{\circ} \mathrm{C}$. Soluble cell lysates were immunoblotted and phosphotyrosine, ERK or phospho-ERK were visualized as reported previously.

Determination of Nitric Oxide (NO) Production After the preincubation of RAW264.7 cells $\left(1 \times 10^{6}\right.$ cells $\left./ \mathrm{ml}\right)$ for 18 $\mathrm{h}$, KML (0 to $60 \mathrm{ng} / \mathrm{ml})$ with LPS $(2.5 \mu \mathrm{g} / \mathrm{ml})$ was incubated for $24 \mathrm{~h}$, as reported previously. The nitrite in culture supernatants was measured by adding $100 \mu \mathrm{l}$ of Griess reagent ( $1 \%$ sulfanilamide and $0.1 \% N$-[1-naphthyl]-ethylenediamine

Table 1. Sequences of the Primers for the Investigated Genes by RT-PCR Analysis

\begin{tabular}{lll}
\hline \hline \multicolumn{2}{r}{ Gene } & \\
& & Primer sequences \\
\hline \multirow{2}{*}{ TNF- $\alpha$} & F & 5'-TTGACCTCAGCGCTGAGTTG-3' \\
& R & 5'-CCTGTAGCCCACGTCGTAGC-3' \\
IL-1 $\beta$ & F & 5'-CAGGATGAGGACATGAGCACC-3' \\
& R & 5'-CTCTGCAGACTCAAACTCCAC-3' \\
IL-3 & F & 5'-GAAGTGGATCCTGAGGACAGATACG-3' \\
& R & 5'-GACCCATGGGCCATGAGGAACATTC-3' \\
IL-6 & F & 5'-GTACTCCAGAAGACCAGAGG-3' \\
& R & 5'-TGCTGGTGACAACCACGGCC-3' \\
IL-10 & F & 5'-CGTCGGATCCGCCATGCCTGGCTCACCACTGCT-3' \\
& R & 5'-CGTCTCTAGATTAGCTTTTCATTTTGATCA-3' \\
IL-23 & F & 5'-AATAATGTGCCCCGTATCCA-3' \\
& R & 5'-CTGGAGGAGTTGGCTGAGTC-3' \\
GAPDH & F & 5'-CACTCACGGCAAATTCAACGGCAC-3' \\
& R & 5'-GACTCCACGACATACTCAGCAC-3'
\end{tabular}


dihydrochloride in 5\% phosphoric acid) to $100 \mu$ samples.

Determination of ROS Generation The level of intracellular ROS was determined by the change in fluorescence resulting from the oxidation of the fluorescent probe $\mathrm{H}_{2}$ DCFDA or DHR123. Briefly, $5 \times 10^{5}$ cells/well were exposed to KML (2 or $10 \mathrm{ng} / \mathrm{ml}$ ) for $30 \mathrm{~min}$. After incubation, cells were then incubated with LPS $(2.5 \mu \mathrm{g} / \mathrm{ml})$ or SNP $(125 \mu \mathrm{M})$ as an inducer of ROS production at $37^{\circ} \mathrm{C}$ for $6 \mathrm{~h}$. Cells were incubated with $50 \mu \mathrm{M} \mathrm{H}_{2}$ DCFDA or $10 \mu \mathrm{M}$ $\mathrm{DHR} 123$ for $1 \mathrm{~h}$ at $37^{\circ} \mathrm{C}$. The degree of fluorescence, corresponding to intracellular ROS, was determined on a FACScan flow cytometer (Becton-Dickinson, San Jose, CA, U.S.A.).

Determination of Phagocytic Uptake To measure the phagocytic activity of RAW264.7 cells, a previously reported method was used with slight modifications. ${ }^{24)}$ RAW264.7 $\left(5 \times 10^{4}\right)$ cells were resuspended in $100 \mu \mathrm{l}$ PBS containing $1 \%$ human $\mathrm{AB}$ serum and incubated with FITC-dextran $(0.1 \mathrm{mg} / \mathrm{ml})$ at $37^{\circ} \mathrm{C}$ and $0{ }^{\circ} \mathrm{C}$ for $30 \mathrm{~min}$. The incubations were stopped by adding $2 \mathrm{ml}$ ice-cold PBS containing $1 \%$ human serum and $0.02 \%$ sodium azide. The cells were washed three times with cold PBS-azide and analyzed by flow cytometry.

Flow Cytometric Analysis The surface level of co-stimulatory molecules (CD40, CD80 and CD86), adhesion molecules (CD18, CD29, CD62L, CD43, CD98 and CD147), and pattern recognition receptors (TLR-2, TLR-4 and dectin-1) in U937 or RAW264.7 cells was determined by flow cytometric analysis, as reported previously. ${ }^{21}$ Stained cells were analyzed on a FACScan.

Cell-Cell or Cell-Extracellular Matrix Protein (Fibronectin) Adhesion Assay U937 cell-cell adhesion assay was performed as reported previously. ${ }^{21,22)}$ Briefly, U937 cells were pre-incubated with KML ( 2 or $10 \mathrm{ng} / \mathrm{ml}$ ) for $1 \mathrm{~h}$ at $37^{\circ} \mathrm{C}$ and were then further incubated with function-activating (agonistic) antibody (MEM101A, $1 \mu \mathrm{g} / \mathrm{ml}$ ) in a 96-well plate. After a 2-h incubation, cultures were examined with an inverted light microscope equipped with a COHU high-performance CCD (Diavert) video camera. Four random fields of each well were captured and analyzed using NIH image software in order to calculate the average size of the clusters. For the cell-fibronectin adhesion assay, U937 cells $\left(5 \times 10^{5}\right.$ cells/well $)$ were seeded on a fibronectin $(50 \mu \mathrm{g} / \mathrm{ml})$ coated plate and incubated for $3 \mathrm{~h}^{25}$ ) After removing unbound cells with PBS, the attached cells were treated with $0.1 \%$ of crystal violet for $15 \mathrm{~min}$. The OD value at $570 \mathrm{~nm}$ was measured by a Spectramax 250 microplate reader.

Statistical Analysis A Student's $t$-test and an one-way ANOVA were used to determine the statistical significance of differences between values for the various experimental and control groups. Data are expressed as means \pm standard errors (S.E.M.) and the results are taken from at least three independent experiments performed in triplicate. $p$ values of 0.05 or less were considered to be statistically significant.

\section{RESULTS}

Effect of KML on the Viability of RAW264.7 and U937 Cells Like EM lectin, KML has also been reported to be one of the strong anti-cancer lectins with direct cytotoxicity. Before starting our experiments, we therefore examined the effect of KML on the viability of RAW264.7 and U937 cells. As Fig. 1 shows, KML dose-dependently suppressed cell viability following 24-h incubation, with $\mathrm{IC}_{50}$ values of 48.7 (U937 cells) and 73.2 (RAW264.7 cells) ng/ml, respectively. In contrast, the growth of Jurkat T cells was strongly blocked with an $\mathrm{IC}_{50}$ value of $4.2 \mathrm{ng} / \mathrm{ml}$. In the case of the 6-h incubation, $500 \mathrm{ng} / \mathrm{ml}$ of KML significantly suppressed the viability of U937 cells but not RAW264.7 cells, up to 40\%, whereas Jurkat $\mathrm{T}$ cells were affected by KML ranged in values from 30 to $500 \mathrm{ng} / \mathrm{ml}$.

KML Differentially Regulates the Expression of Proinflammatory Cytokines Induced by LPS Stimulation Cytokines (such as IL-1 $\beta$, IL-6 and TNF- $\alpha$ ) are known to be pro-inflammatory cytokines that possess a multitude of biological activities linked to normal defense responses and the immunopathology of acute or chronic inflammatory diseases such as asthma, septic shock and rheumatoid arthritis, as well as autoimmune diseases. ${ }^{26,27)}$ Therefore, we examined whether KML was capable of effectively regulating cytokine expression in murine macrophages (RAW264.7), by using a semi-quantitative RT-PCR method. As shown in Fig. 2A, KML $(2,10 \mathrm{ng} / \mathrm{ml})$ significantly modulated the transcriptional levels of these cytokines. Thus, KML markedly upregulated the normal expression of IL-3 and IL-23, while it blocked TNF- $\alpha$ (at $10 \mathrm{ng} / \mathrm{ml}$ ) and IL-10 expression (at $2 \mathrm{ng} / \mathrm{ml}$ ). Under LPS co-stimulation conditions, KML significantly blocked IL-10 expression, whereas IL-23 and TNF- $\alpha$ were markedly up-regulated by KML treatment.

Since the up-regulating effect of KML on IL-3 expression was very promising, we next evaluated KML-mediated IL-3 induction in terms of signaling events. Figure $2 \mathrm{~B}$ depicts that
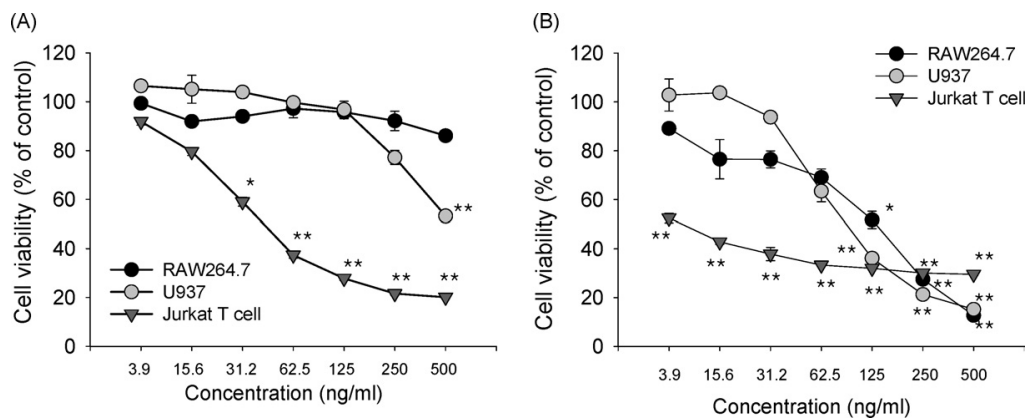

Fig. 1. The Effect of KML on Viability of RAW264.7, U937 and Jurkat T Cells

Cells $\left(0.5 \times 10^{6}\right.$ cells $\left./ \mathrm{ml}\right)$ were incubated with various concentrations of KML for $6 \mathrm{~h}(\mathrm{~A})$ or $24 \mathrm{~h}(\mathrm{~B})$. Cell viability was assayed by a conventional MTT method as described in Materials and Methods. Data represent mean \pm S.E.M. of three independent observations performed in triplicate. $* p<0.05$ and $* * p<0.01$ compared to normal. 
(A)

\begin{tabular}{rrrrrrr}
$\mathrm{LPS}(2.5 \mu \mathrm{g} / \mathrm{ml})$ & - & + & + & + & - & - \\
$\mathrm{KML}(\mathrm{ng} / \mathrm{ml})$ & - & - & 2 & 10 & 2 & 10 \\
\hline
\end{tabular}

(C)

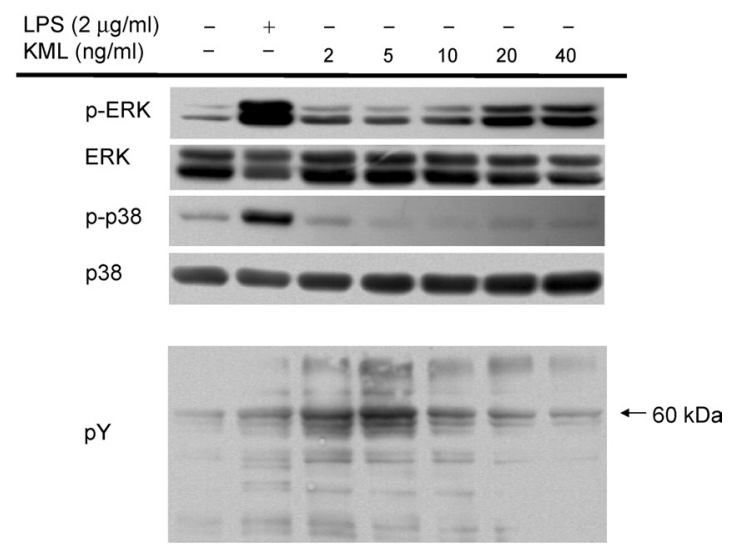

(B)

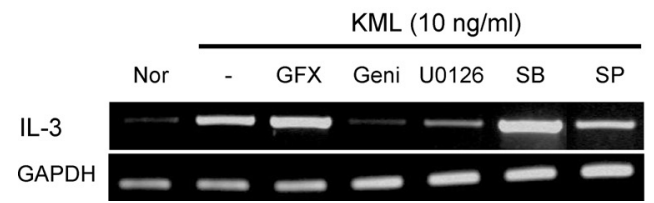

Fig. 2. The Effect of KML on the Expression of Cytokines and Chemokines in Activated RAW264.7 Cells

(A, B) RT-PCR analysis : RAW264.7 cells $\left(1 \times 10^{7}\right.$ cells $\left./ \mathrm{ml}\right)$ were incubated with KML $(2,10 \mathrm{ng} / \mathrm{ml})$ in the presence or absence of LPS $(2.5 \mu \mathrm{g} / \mathrm{ml})$ for $6 \mathrm{~h}$. The $\mathrm{mRNA}$ levels of cytokines were determined by a semi-quantitative RT-PCR. The results represent one experiment out of three. (C) Immunoblotting analysis: RAW264.7 cells $\left(5 \times 10^{6} \mathrm{cells} / \mathrm{ml}\right)$ were stimulated with LPS ( $2.5 \mu \mathrm{g} / \mathrm{ml}$ ) or KML (2 to $40 \mathrm{ng} / \mathrm{ml}$ ) for $30 \mathrm{~min}$. After immunoblotting, the levels of tyrosine phosphorylation (PY) of proteins, phospho (p)-ERK, p-p38, ERK and $\mathrm{p} 38$ were identified by phospho-specific antibody to PY, p-ERK, ERK, p-p38 and p38. The results represent one experiment out of three. GFX: GF109203X, 10 $\mu \mathrm{M}$; Geni: genistein, $50 \mu \mathrm{M}$; U0126, $20 \mu \mathrm{M} ; \mathrm{SB}: \mathrm{SB} 203580,10 \mu \mathrm{M} ; \mathrm{SP}: \mathrm{SP} 600125,25 \mu \mathrm{M}$.

(A)

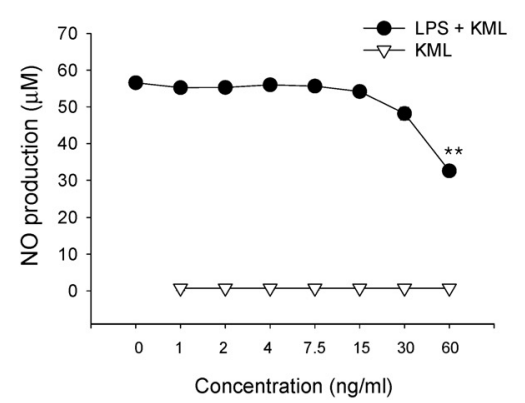

(B)

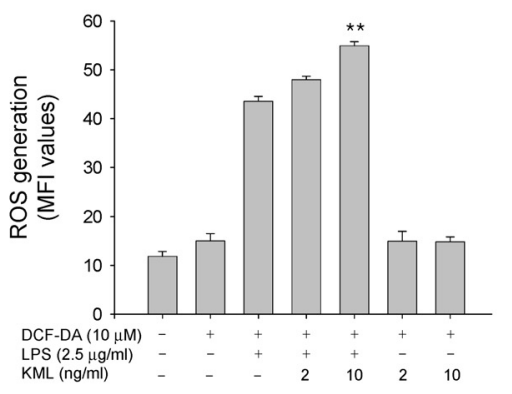

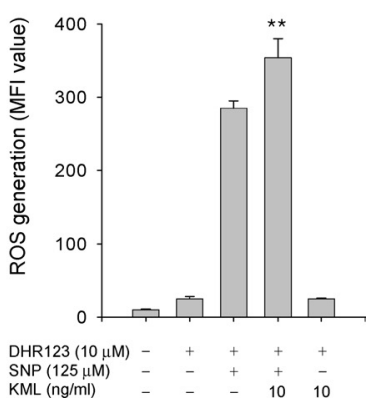

1010

Fig. 3. The Effect of KML on the Production of NO and the Generation of ROS in LPS or SNP-Treated RAW264.7 Cells

(A) NO production: RAW264.7 cells $\left(1 \times 10^{6}\right.$ cells/ml) were stimulated by LPS $(2.5 \mu \mathrm{g} / \mathrm{ml})$ with KML ( 0 to $\left.60 \mathrm{ng} / \mathrm{ml}\right)$ for $24 \mathrm{~h}$. Supernatants were collected and the nitrite (NO) concentration from the supernatants was determined by Griess reagent, as described in Materials and Methods. (B) ROS generation: RAW264.7 cells $\left(1 \times 10^{6} \mathrm{cells} / \mathrm{ml}\right)$ were stimulated with LPS $(2.5 \mu \mathrm{g} / \mathrm{ml})$ or SNP $(125 \mu \mathrm{M})$ in the presence or absence of KML $(2,10 \mathrm{ng} / \mathrm{ml})$ for $3 \mathrm{~h}$. ROS was determined by flow cytometric analysis as described in Materials and Methods. Data represent mean \pm S.E.M. of three independent observations performed in triplicate. $* * p<0.01$ compared to control (LPS or SNP alone).

the induction of IL-3 by KML seems to require the enzyme activities of protein tyrosine kinases and the extracellular signal-related kinase (ERK). Namely, the broad-spectrum protein kinase inhibitor, genistein (Geni: $50 \mu \mathrm{M})$, and an ERK kinase (MEK) inhibitor, U0126 $(20 \mu \mathrm{M})$, strongly blocked KML-mediated expression of IL-3. Moreover, a broad-spectrum protein kinase $\mathrm{C}$ inhibitor GF109203X (GFX: $10 \mu \mathrm{M}$ ) and a p38 inhibitor SB203580 (SB: $10 \mu \mathrm{M})$ enhanced IL-3 expression (Fig. 2B, upper panel). To verify the mRNA results obtained by the treatment with specific inhibitors, immunoblotting experiments were conducted. In agreement, tyrosine phosphoproteins (e.g. $60 \mathrm{kDa}$ ) and ERK activation, judged by its phosphorylation level, was observed remarkably without alteration of total forms (Fig. 2C). However, there was no up-regulation of phospho-p38 when using up to $40 \mathrm{ng} / \mathrm{ml}$ of KML.
KML Modulates the Production of NO and ROS Since NO and ROS are known to be representative toxic and proinflammatory mediators in many different acute and chronic inflammatory diseases, as well as in normal defense reactions, ${ }^{28)}$ we addressed whether KML modulated the production of NO and ROS in LPS or SNP-treated macrophages. According to a nitrite assay, KML dose-dependently inhibited NO production up to $40 \%$ (Fig. 3A). However, mRNA expression of inducible NO synthase (iNOS) was not altered by treatment with KML up to $40 \mathrm{ng} / \mathrm{ml}$ (data not shown). KML itself did not induce NO production up to $1 \mathrm{mg} / \mathrm{ml}$ (data not shown), suggesting that there were no macrophage-activating immunogens such as pathogen-associated molecular patterns. In the case of ROS generation, KML positively modulated ROS generation induced by LPS $(2.5 \mu \mathrm{g} / \mathrm{ml})$ or SNP $(125 \mu \mathrm{M})$. Thus, KML only enhanced 
(A)

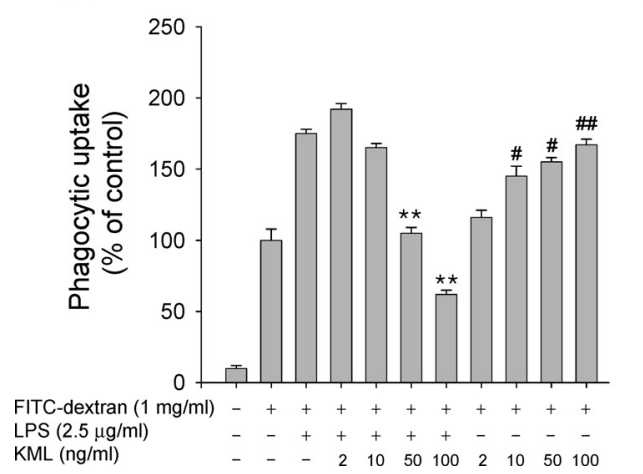

(B)

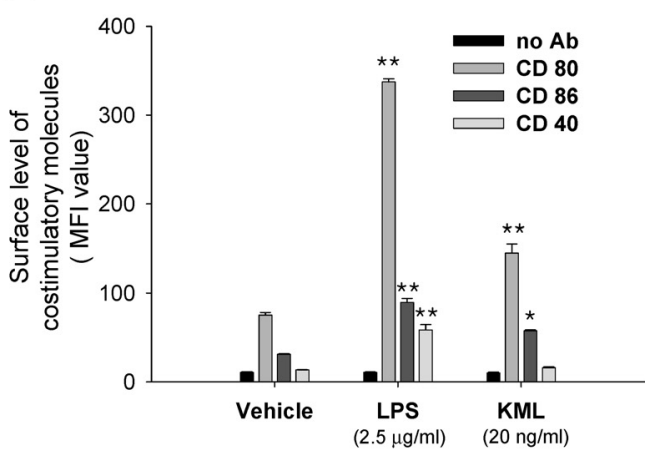

Fig. 4. The Effect of KML on the Phagocytic Uptake of RAW264.7 Cells and Their Co-stimulatory Molecule (CD80 and CD86) Levels Following LPS Exposure

(A) Phagocytosis: RAW264.7 cells $\left(2 \times 10^{6}\right.$ cells $\left./ \mathrm{ml}\right)$, pretreated with KML ( 0 to $\left.100 \mathrm{ng} / \mathrm{ml}\right)$, were stimulated with FITC-dextran ( $\left.1 \mathrm{mg} / \mathrm{ml}\right)$ in the presence or absence of LPS $(2.5 \mu \mathrm{g} / \mathrm{ml})$ for $6 \mathrm{~h}$. The extent of the phagocytic uptake was determined by flow cytometric analysis, as described in Materials and Methods. (B) Costimulatory molecule levels: RAW264.7 cells $\left(2 \times 10^{6}\right.$ cells $\left./ \mathrm{ml}\right)$ were stimulated in the presence or absence of LPS $(2.5 \mu \mathrm{g} / \mathrm{ml})$ or KML $(20 \mathrm{ng} / \mathrm{ml})$ for $12 \mathrm{~h}$. The surface level of the co-stimulatory molecules (CD40, CD80 and CD86) was determined by flow cytometric analysis. Data represent mean \pm S.E.M. of three independent observations performed in triplicate. \# $p<0.05$ and $\# p<0.01$ compared to FITC-dextran (A), $* p<0.05$ and $* * p<0.01$ compared to LPS (A) or normal (B).

LPS-induced ROS generation, whereas KML alone did not up-regulate the reactivity of ROS. In agreement, moreover, SNP-induced ROS formation was also significantly boosted at $10 \mathrm{ng} / \mathrm{ml}$. The standard compound, N-MMA, showed significant inhibitory effects on $\mathrm{NO}$ production, with an $\mathrm{IC}_{50}$ value of $206.7 \mu \mathrm{m}$ upon LPS stimulation.

KML Differentially Modulates the Phagocytic Uptake and Surface Level of Costimulatory Molecules The phagocytic uptake by macrophages plays an important role in removing foreign materials, clearing cell debris and turning their role into antigen-presenting cells by the expression of higher levels of co-stimulatory molecules, such as CD80 and CD86, which mediate the interaction between $\mathrm{T}$ cells and macrophages. ${ }^{29)}$ It is interesting to note that KML showed different modulatory patterns on the up-regulation of phagocytic uptake in the presence or absence of LPS. As Fig. 4A displays, KML dose-dependently diminished LPS-mediated up-regulation of dextran uptake. However, the phagocytosis of RAW264.7 cells under normal culture conditions was strongly enhanced by KML treatment in a dose-dependent manner. In agreement, KML itself up-regulated surface levels of CD80 and CD86, although LPS also significantly increased CD40 levels in addition to CD80 and CD86 (Fig. 4B).

KML Regulates the Surface Level of $\beta 1$-Integrins (CD29) and Their Functional Activation The activation of adhesion molecules plays an important role in regulating innate and adaptive immunity since these molecules modulate immune cell migration to inflamed tissues and heterotypic cell-cell adhesion between those cells. ${ }^{30)}$ The effective blockade or activation of these events is, therefore, regarded as a therapeutic target that suppresses chronic inflammatory symptoms or enhances host defense mechanisms. ${ }^{31}$ ) As a result, the functional regulation of adhesion molecules has been attempted by developing specific antibodies or exploring small molecules that modulate intracellular signaling. ${ }^{32)}$ Accordingly, we investigated the modulatory effects of KML on the surface levels of adhesion molecules and their the functional activation using a cell-cell adhesion assay, which was established with U937 cells and function-activating (agonistic) antibody to $\beta 1$-integrins (CD29) and CD43, ${ }^{32}$ and a cell-fibronectin (an extracellular matrix protein) adhesion assay. $\left.{ }^{25}\right)$

As shown in Fig. 5A, KML treatment remarkably enhanced CD29 (also CD43) level compared to other adhesion molecules and other stimuli such as LPS. To confirm the upregulation of surface CD29 level by KML, effects of KML under functional activation (linked to inducing cell-cell clustering) of CD29 by its agonistic antibody was evaluated. Interestingly, the cell-cell clustering induced by CD29 was strongly enhanced by KML (Fig. 5B), while CD98 and CD147-induced aggregation events were not significantly altered (data not shown). In contrast, $10 \mathrm{ng} / \mathrm{ml}$ of KML only significantly increased fibronectin-mediated U937 cell adhesion, a specific adhesion event mediated by CD29 (Fig. 5C), suggesting that KML may differentially modulate cell-cell and cell-fibronectin adhesion. Indeed, cytochalasin, a strong actin polymerization inhibitor, strongly blocked CD29-mediated cell-cell adhesion, but not fibronectin-cell adhesion (data not shown).

KML Strongly Modulates the Surface Level of TLR-2 To test whether KML is able to regulate the expressional and functional activation of PRRs such as dectin-1 and TLRs, ${ }^{33,34)}$ we examined the surface levels of these molecules after treatment of RAW264.7 cells with KML. As shown in Fig. 6A, KML significantly enhanced the surface levels of TLR-2 and dectin-1, but not TLR-4. However, the up-regulation of TLR-2 by KML seems not to be relevant to regulating TLR-2-mediated NO production induced by peptidoglycan as shown in the case of LPS, as peptidoglycan activity was not additive or synergistic with KML (or LPS) co-treatment (Fig. 6B).

D-Galactose Treatment Abolished KML-Mediated NO Inhibition To test whether KML effect was mediated by binding to surface proteins with galactose as reported previously, ${ }^{35)}$ D-galactose was co-treated with KML under LPS-induced NO production condition. As Fig. 7 shows, LPS-induced NO production was significantly decreased in response to KML. However, galactose strongly abrogated KML-mediated NO inhibition in a dose-dependent manner, suggesting that galactose may play a critical role in KML-mediated inhibition of LPS response. 

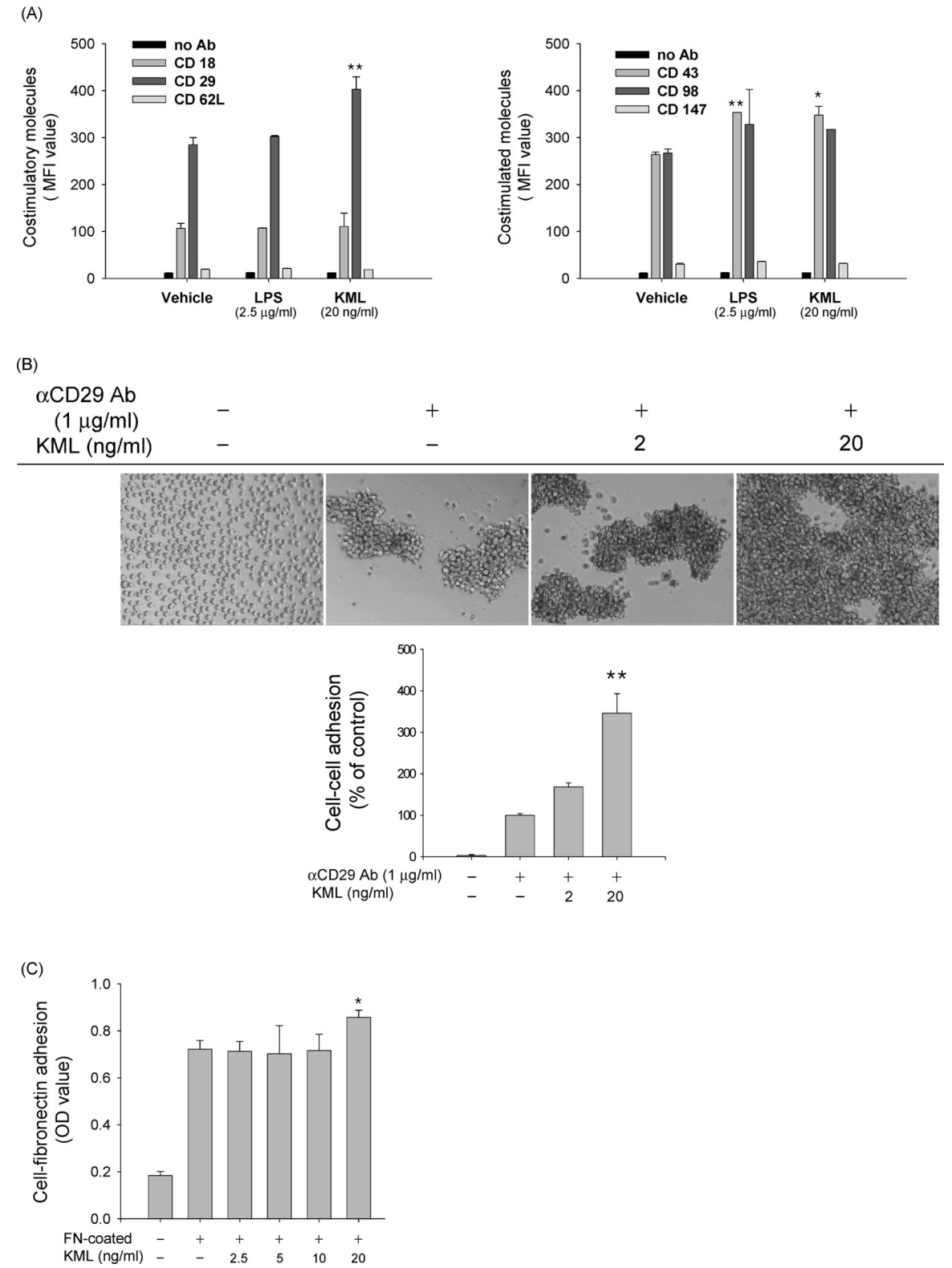

Fig. 5. The Effects of KML on the Surface Levels of Adhesion Molecules and CD29-Mediated Adhesion Events

(A) Surface levels of adhesion molecules: U937 cells $\left(1 \times 10^{6}\right.$ cells $\left./ \mathrm{ml}\right)$ were incubated with LPS $(2.5 \mu \mathrm{g} / \mathrm{ml})$ or KML $(20 \mathrm{ng} / \mathrm{ml})$. The surface level of adhesion molecules (CD18, CD29, CD62L, CD43, CD98 and CD147) was determined by flow cytometric analysis. (B) Cell-cell adhesion: U937 cells $\left(1 \times 10^{6}\right.$ cells $\left./ \mathrm{ml}\right)$ were incubated with KML (20 ng/ml) in the presence or absence of pro-aggregative antibody to CD29 (MEM 101A, $1 \mu \mathrm{g} / \mathrm{ml}$ ) for $3 \mathrm{~h}$. The images of the cells in culture were obtained using an inverted phase contrast microscope attached to a video camera. The images were captured using NIH image software. (C) Cell-fibronectin adhesion: U937 cells $\left(1 \times 10^{6}\right.$ cells/ml), pretreated with various concentration of KML, were seeded on fibronectin $(50 \mu \mathrm{g} / \mathrm{ml})$-coated plates and further incubated for $3 \mathrm{~h}$. The attached cells were determined by crystal violet assay, as described in Materials and Methods. Data represent mean \pm S.E.M. of three independent observations performed in triplicate. $* p<0.05$ and $* * p<0.01$ compared to normal (A) or control $(\mathrm{B}, \mathrm{C})$.

\section{DISCUSSION}

The data presented in this paper indicate that KML can exert significant immunomodulatory effects on various macrophage-mediated immune responses. Thus, KML modulated the expression of cytokines [IL-3, IL-10, IL-23 and TNF- $\alpha$ (Fig. 1)], NO production (Fig. 2), ROS generation (Fig. 3), phagocytic uptake and the surface levels of co-stimulatory molecules [CD80 and CD86 (Fig. 4)], the surface level of adhesion molecule (CD29) and its functional activation assessed by cell adhesion (Fig. 5), and the surface levels of PRRs [dectin-1 and TLR-2 (Fig. 6)] at concentrations ranging from 2 to $20 \mathrm{ng} / \mathrm{ml}$. The suppressive or enhancing effects of KML on these immunological parameters were not due to non-specific activity, since there was no cytotoxicity at pharmacologically-effective doses [less than $100 \mathrm{ng} / \mathrm{ml}$ (at 6h) or $60 \mathrm{ng} / \mathrm{ml}$ (at 24-h)] (Fig. 1), and seem to be mediated by cell surface D-glactose (or even $N$-acetyl-D-galactoseamine), according to co-treatment effect by which D-galactose abolished KML-mediated inhibition of NO production (Fig. 7). Even though we found that KML has significant modulatory activities at broad-spectrum ranged concentrations ( 0 to $20 \mathrm{ng} / \mathrm{ml}$ ), these immunomodulatory patterns were also similarly reported in previous reports regarding leukocyte (lymphocyte) proliferation and the regulation of $\mathrm{T}$ helper type I (Th1)/Th2 balance. ${ }^{19)}$ Considering that these macrophagemediated immunological parameters are important in cancerous and infectious states, the regulatory effects of KML may 
(A)

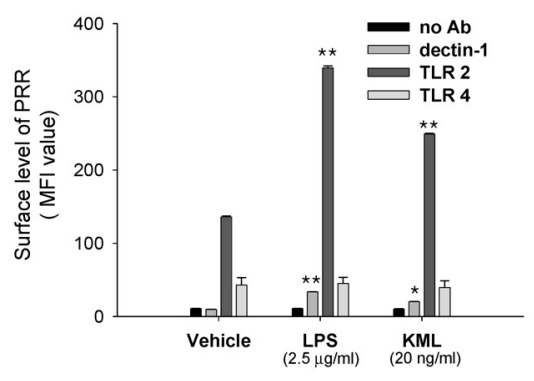

(B)

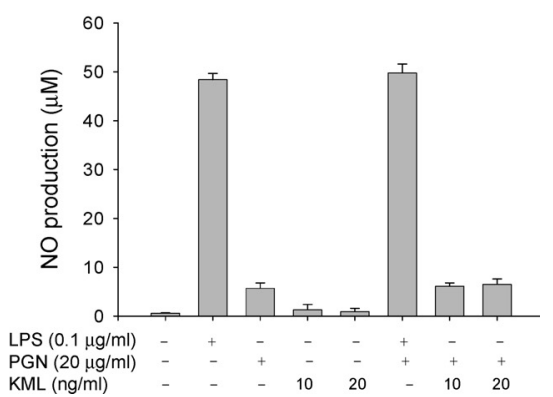

Fig. 6. The Effects of KML on the Surface Levels of PRRs (Dectin-1, TLR-2 and TLR-4) and PRR-Mediated NO Production

(A) RAW264.7 cells $\left(2 \times 10^{6}\right.$ cells $\left./ \mathrm{ml}\right)$ were stimulated with LPS $(2.5 \mu \mathrm{g} / \mathrm{ml})$ or KML $(20 \mathrm{ng} / \mathrm{ml})$ for $12 \mathrm{~h}$. The surface levels of dectin-1, TLR-2 and TLR-4 were determined by flow cytometric analysis. (B) NO assay: RAW264.7 cells $\left(1 \times 10^{6}\right.$ cells $\left./ \mathrm{ml}\right)$ were stimulated by peptidoglycan (PGN, $20 \mu \mathrm{g} / \mathrm{ml}$, left panel) $\beta$-glucan curdlan $(100 \mu \mathrm{g} / \mathrm{ml}$, right panel) with LPS $(2.5 \mu \mathrm{g} / \mathrm{ml})$ or KML $(10,20 \mathrm{ng} / \mathrm{ml})$ for $24 \mathrm{~h}$. Supernatants were collected and the nitrite (NO) concentration from the supernatants was determined by Griess reagent, as described in Materials and Methods. Data represent mean \pm S.E.M. of three independent observations performed in triplicate. $* p<0.05$ and $* * p<0.01$ compared to normal.

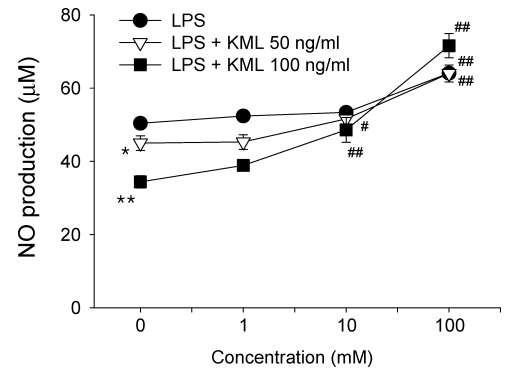

Fig. 7. The Effect of D-Galactose on KML-Mediated Inhibition of LPSInduced NO Production

RAW264.7 cells $\left(2 \times 10^{6}\right.$ cells $\left./ \mathrm{ml}\right)$, pretreated with D-galactose (0 to $\left.100 \mathrm{~mm}\right)$, were stimulated with LPS $(2.5 \mu \mathrm{g} / \mathrm{ml})$ and KML $(50$ or $100 \mathrm{ng} / \mathrm{ml})$ for $24 \mathrm{~h}$. Supernatants were collected and the nitrite $(\mathrm{NO})$ concentration from the supernatants was determined by Griess reagent, as described in Materials and Methods. Data represent mean \pm S.E.M. of three independent observations performed in triplicate. $* p<0.05$ and $* * p<0.01$ compared to LPS alone, and $\# p<0.05$ and $\# p<0.01$ compared to LPS +KML.

thus contribute to the pharmacological actions of Korean mistletoe.

Although some of KML's effects participated in down-regulating IL-10 expression and NO production from activated macrophages, most effects obtained in this study seem to be involved in stimulating or activating overall macrophage function, in agreement with previous reports in which it has been reported that (1) single or long-term treatments in mice and humans evokes increased levels of cytokines (IL-1 $\beta$, IL5 , TNF- $\alpha$ and GM-CSF) ${ }^{18,36,37)}$ and (2) the mistletoe-originated lectins stimulate phagocytic uptake of macrophages. ${ }^{38)}$ In our data, we clearly obtained a similar pattern of cytokine expression (up-regulation of TNF- $\alpha$ and IL-23 following LPS exposure) and phagocytic profiles (Figs. 2, 3). Additionally, we also found that KML especially stimulated ROS generation. Considering that these KML-mediated immunostimulatory effects can participate in host tumor immunity, ${ }^{16,17)}$ it has been speculated that these modulatory effects may orchestrate its anti-tumor immune responses. Nonetheless, the most interesting aspect was that KML was able to stimulate the expression of IL-3 (Fig. 2A), a cytokine involved in the regulation of hematopoietic stem cell proliferation and eosinophil differentiation. ${ }^{39)}$ This new finding seems to be valuable, since it has not been understood why the aqueous extract of EM or its lectins can increase the number of granulocytes and eosinophils. ${ }^{40,41)}$ Thus, the up-regulation of IL-3 by KML may be linked to its regulatory effect of blood cell numbers.

Another major effect of KML treatment appears to alter surface membrane conditions, as KML has been implicated to first bind to cell surface proteins with D-galactose and $\mathrm{N}$ acetyl-D-galactoseamine ${ }^{35)}$ and indeed we also found that Dgalactose treatment strongly abrogated KML-mediated inhibition of LPS-induced NO production (Fig. 7). Thus, it strongly up-regulated the surface levels of glycoproteins including co-stimulatory molecules (CD80 and CD86) (Fig. 4), adhesion molecules (CD29) (Fig. 5) and PRRs (dectin-1 and TLR-2) (Fig. 6). Firstly, the up-regulation of surface level of CD29 seems to be in relevant to functional activation of CD29 itself. Thus, CD29 agonistic antibody-induced U937 cell-cell adhesion, a specific homotypic cell-cell adhesion event activated by CD29, was clearly up-regulated by KML treatment (Fig. 5B). This adhesion pattern was also demonstrated by U937 cell adhesion to fibronectin, an extracellular matrix protein with a CD29 binding domain. As Fig. 5C shows, KML $(20 \mathrm{ng} / \mathrm{ml})$ significantly enhanced U937 cell binding to fibronectin-coated wells, indicating that KML increased functional activation of CD29. Secondly, it is notable that KML up-regulated the surface levels of PRRs [dectin-1, a receptor of $\beta$-glucan and TLR-2, a receptor of Gram (+) bacterium peptidoglycan $(\mathrm{PGN})]$, since the receptors play central roles in macrophage-mediated innate immunity. ${ }^{42,43)}$ To evaluate whether KML was able to modulate functional activation of these receptors, we used $\beta$-glucan or PGN-induced NO production assays. Unfortunately, there was no additive or synergistic induction of NO production by KML cotreatment, upon TLR-2 or dectin-1 activating conditions, suggesting either no functional modulation by KML or the involvement of other biological responses mediated by the receptors. A similar NO-producing pattern to combination treatment of PGN with LPS was observed, such that the potential role of KML on the regulation of TLR-2 or TLR-4 functions may have to be addressed using other biological parameters such as cytokine production. Finally, we also observed that the up-regulation of CD80 and CD86 was a clear phenomenon resulting from KML treatment. Considering that these molecules play a critical role in the proliferation, activation and differentiation of $\mathrm{T}$ cells, ${ }^{44)}$ this effect suggests the possibility that KML may positively regulate $\mathrm{T}$ cell expansion. Recent reports and our results, however, indicate 
that KML was not able to boost $\mathrm{T}$ cell proliferation, ${ }^{17}$ but rather block the proliferation of these cells in a dose-dependent manner (data not shown). In spite of this, it is interesting to note that KML participates in modulating the balance of Th1/Th2 responses, suggesting that the alteration of co-stimulatory molecules by KML may be linked to modulating $\mathrm{T}$ cell differentiation, but not proliferation.

Although the molecular mechanism by which KML upregulates macrophage responses has not been fully elucidated, KML may not modulate a common pathway of macrophage responses. To date, several important common pathways have been identified. One of these pathways is known to be the nuclear factor (NF)- $\kappa \mathrm{B}$-mediated biological phenomena, as it controls the expression of various protein markers such as cytokines and surface glycoproteins indicating the activation of macrophages. ${ }^{45,46)}$ This is also the reason why many have tried to develop potent inhibitors or activators of NF- $\kappa$ B as novel anti-inflammatory or immunostimulatory drugs (e.g. sesquiterpene lactone compounds and $\beta$ glucan). ${ }^{47,48)}$ Our data, however, seem to show that the NF$\kappa \mathrm{B}$ is not a common target of KML. This is because its modulatory patterns toward the expression of NF- $\kappa \mathrm{B}$-dependent pro-inflammatory genes were variable. Thus, KML did not strongly induce IL- $1 \beta$ and IL-6, which are representative NF$\kappa$ B-dependent cytokines (Fig. 2A). Furthermore, KML did not increase luciferase activity induced by NF- $\kappa \mathrm{B}$ binding, and the phosphorylation of $\mathrm{I} \kappa \mathrm{B} \alpha$ and its degradation (data not shown), which are critical steps for NF- $\kappa \mathrm{B}$ translocation. ${ }^{49)}$ Nevertheless, Figs. $2 \mathrm{~B}$ and C display that ERK activation and tyrosine phosphorylation of p60 seem to play crucial roles in KML-induced IL-3 production, since pharmacological intervention with specific inhibitors (U0126 and genistein) of ERK and tyrosine phosphorylation strongly suppressed IL-3 induction by KML exposure (Figs. 2B, C). However, KML treatment seems not to be linked to simple disconnection of whole signaling responses, as the surface levels of glycoproteins such as CD40 and CD147 and the phosphorylation of p38, [as well as other signaling events such as JNK phosphorylation (data not shown)], were not changed. How KML can activate macrophages, therefore, will be further investigated in terms of signaling and potential cooperation between surface glycoproteins.

In summary, we have shown that KML differentially modulated macrophage-mediated immune responses. Thus, it clearly blocked some LPS-induced events, such as the expression of IL-10, NO production and phagocytic uptake. On the other hand, it also enhanced macrophage responses in the absence or presence of LPS. (1) The expression of various cytokines (IL-3, IL-23 and TNF- $\alpha$ ), (2) ROS generation, (3) phagocytic uptake and (4) surface levels of some glycoproteins (co-stimulatory molecules, PRRs and adhesion molecules) as well as (5) the functional activation of adhesion molecules assessed by cell-cell or fibronectin adhesion events were the up-regulated outcomes by KML treatment. In contrast, D-galactose abolished KML inhibition under LPSinduced NO production. Therefore, these data suggest that KML may have regulatory functions on macrophage-mediated innate and adaptive responses involved in KML's therapeutic effects such as anti-cancer immunological activities via binding to membrane proteins with galactose moiety. However, to pharmacologically apply, detailed safety study should be followed, although almost identical lectin EML is clearly known to be non-toxic in clinical use. ${ }^{5)}$ Furthermore, how KML can carry out various immunopharmacological actions at the same time and how KML interacts with surface receptors should be further explored for verifying its molecular action mechanism.

Acknowledgements This work was supported by a grant (ARPC 2006 to J.Y.C., M.K., S.H.) from the Korean Government. We also acknowledge to The Central Laboratory of Kangwon National University for flow cytometric analysis.

\section{REFERENCES}

1) Kinne R. W., Brauer R., Stuhlmuller B., Palombo-Kinne E., Burmester G. R., Arthritis Res., 2, 189-202 (2000).

2) Kumar S., Jack R., J. Endotoxin Res., 12, 278-284 (2006)

3) Gracie J. A., Forsey R. J., Chan W. L., Gilmour A., Leung B. P., Greer M. R., Kennedy K., Carter R., Wei X. Q., Xu D., Field M., Foulis A., Liew F. Y., McInnes I. B., J. Clin. Invest., 104, 1393-1401 (1999).

4) Michaelsson E., Holmdahl M., Engstrom A., Burkhardt H., Scheynius A., Holmdahl R., Eur. J. Immunol., 25, 2234-2241 (1995).

5) Schoffski P., Riggert S., Fumoleau P., Campone M., Bolte O., Marreaud S., Lacombe D., Baron B., Herold M., Zwierzina H., WilhelmOgunbiyi K., Lentzen H., Twelves C., Ann. Oncol., 15, 1816-1824 (2004).

6) Bishop T. H., Med. World, 75, 439-442 (1951).

7) Jimenez M., Andre S., Siebert H. C., Gabius H. J., Solis D., Glycobiology, 16, 926-937 (2006).

8) Mellstrand S. T., Samuelsson G., Eur. J. Biochem., 32, 143-147 (1973).

9) Orhan D. D., Kupeli E., Yesilada E., Ergun F., Z. Naturforsch., 61c, 26-30 (2006)

10) Samuelsson G., Sven Farm. Tidskr., 63, 415-425 (1959).

11) Yoon T. J., Yoo Y. C., Kang T. B., Shimazaki K., Song S. K., Lee K. H., Kim S. H., Park C. H., Azuma I., Kim J. B., Cancer Lett., 136, 33-40 (1999).

12) Lee H. S., Kim Y. S., Kim S. B., Choi B. E., Woo B. H., Lee K. C., Cell. Mol. Life Sci., 55, 679-682 (1999).

13) Park W. B., Ju Y. J., Han S. K., Arch. Pharm. Res., 21, 429-435 (1998).

14) Peumans W. J., Verhaert P., Pfuller U., Van Damme E. J., FEBS Lett., 396, 261-265 (1996).

15) Schumacher U., Adam E., Kretzschmar H., Pfuller U., Acta Histochem., 96, 399-403 (1994).

16) Choi S. H., Lyu S. Y., Park W. B., Arch. Pharm. Res., 27, 68-76 (2004).

17) Lyu S. Y., Choi S. H., Park W. B., Arch. Pharm. Res., 25, 93-101 (2002).

18) Yoon T. J., Yoo Y. C., Kang T. B., Baek Y. J., Huh C. S., Song S. K., Lee K. H., Azuma I., Kim J. B., Int. J. Immunopharmacol., 20, 163172 (1998).

19) Lyu S. Y., Park W. B., J. Biochem. Mol. Biol., 39, 662-670 (2006).

20) Yoon T. J., Yoo Y. C., Kang T. B., Song S. K., Lee K. B., Her E., Song K. S., Kim J. B., Arch. Pharm. Res., 26, 861-867 (2003).

21) Cho J. Y., Fox D. A., Horejsi V., Sagawa K., Skubitz K. M., Katz D. R., Chain B., Blood, 98, 374-382 (2001).

22) Cho J. Y., Skubitz K. M., Katz D. R., Chain B. M., Exp. Cell Res., 286 $1-11(2003)$

23) Park J. H., Hyun C. K., Shin H. K., Cancer Lett., 126, $43-48$ (1998).

24) Duperrier K., Eljaafari A., Dezutter-Dambuyant C., Bardin C., Jacquet C., Yoneda K., Schmitt D., Gebuhrer L., Rigal D., J. Immunol. Methods, 238, 119-131 (2000).

25) Larrucea S., Gonzalez-Rubio C., Cambronero R., Ballou B., Bonay P., Lopez-Granados E., Bouvet P., Fontan G., Fresno M., Lopez-Trascasa M., J. Biol. Chem., 273, 31718-31725 (1998).

26) Pharoah D. S., Varsani H., Tatham R. W., Newton K. R., de Jager W. Prakken B. J., Klein N., Wedderburn L. R., Arthritis Res. Ther, 8, R50 (2006).

27) Szekanecz Z., Szucs G., Szanto S., Koch A. E., Curr. Drug Targets, 7 , 91-102 (2006). 
28) Guzik T. J., Korbut R., Adamek-Guzik T., J. Physiol. Pharmacol., 54, 469-487 (2003).

29) Hoebe K., Janssen E. M., Kim S. O., Alexopoulou L., Flavell R. A., Han J., Beutler B., Nat. Immunol., 4, 1223-1229 (2003).

30) Arnaout M. A., Mahalingam B., Xiong J. P., Annu. Rev. Cell Dev. Biol., 21, 381-410 (2005).

31) Chaudhuri A., N. Engl. J. Med., 354, 644-645 (2006).

32) Cho J. Y., Kim A. R., Jung J. H., Chun T., Rhee M. H., Yoo E. S., Eur. J. Pharmacol., 492, 85-94 (2004).

33) Muzio M., Polntarutti N., Bosisio D., Prahladan M. K., Mantovani A., Eur. Cytokine Netw., 11, 489-490 (2000).

34) Brown G. D., Nat. Rev. Immunol., 6, 33- 43 (2006).

35) Doser C., Doser M., Hulsen H., Mechelke F., Arzneim.-Forsch., 39, 647-651 (1989).

36) Kovacs E., Biomed. Pharmacother, 54, 305-310 (2000).

37) Joller P. W., Menrad J. M., Schwarz T., Pfuller U., Parnham M. J., Weyhenmeyer R., Lentzen H., Arzneim.-Forsch., 46, 649—653 (1996).

38) Frank U., Engels I., Wagner A., Lacour M., Daschner F. D., Eur. J. Clin. Microbiol. Infect. Dis., 22, 501-503 (2003).
39) Jakimiuk B., Mroczko B., Szmitkowski M., Pol. Arch. Med. Wewn., 112, 1497-1504 (2004).

40) Huber R., Rostock M., Goedl R., Ludtke R., Urech K., Buck S., Klein R., Eur. J. Med. Res., 10, 411-418 (2005).

41) Huber R., Rostock M., Goedl R., Ludtke R., Urech K., Klein R., J. Soc. Integr. Oncol., 4, 3-7 (2006).

42) Brown G. D., Nat. Rev. Immunol., 6, 33-43 (2006).

43) Buzas E. I., Gyorgy B., Pasztoi M., Jelinek I., Falus A., Gabius H. J., Autoimmunity, 39, 691-704 (2006).

44) Collins M., Ling V., Carreno B. M., Genome Biol., 6, 223.1-223.7 (2005).

45) Ali S., Mann D. A., Cell Biochem. Funct., 22, 67-79 (2004).

46) Gilroy D. W., Lawrence T., Perretti M., Rossi A. G., Nat. Rev. Drug Discov., 3, 401-416 (2004).

47) Cho J. Y., Baik K. U., Jung J. H., Park M. H., Eur. J. Pharmacol., 398, 399-407 (2000)

48) Li-Weber M., Giaisi M., Treiber M. K., Krammer P. H., Eur. J. Immunol., 32, 3587-3597 (2002).

49) Tergaonkar V., Int. J. Biochem. Cell Biol., 38, 1647-1653 (2006). 